\title{
PHYTOCHEMICAL AND ETHNOPHARMACOLOGICAL REVIEW OF HETEROPYXIS NATALENSIS
}

\author{
ALFRED MAROYI \\ Department of Botany, Medicinal Plants and Economic Development Research Centre, University of Fort Hare, Private Bag X1314, Alice \\ 5700, South Africa. Email: amaroyi@ufh.ac.za
}

Received: 03 November 2018, Revised and Accepted: 12 December 2018

\begin{abstract}
The bark, leaves, roots, and twigs of Heteropyxis natalensis are widely used as herbal medicines in Southern Africa. The aim of this study was to review the phytochemical and ethnopharmacological properties of $H$. natalensis so as to provide baseline data required for evaluating the therapeutic potential of the species. Information on the botanical profile, medicinal uses, phytochemistry, and pharmacological properties of $H$. natalensis was undertaken using databases such as ScienceDirect, SciFinder, PubMed, Google Scholar, Medline, SCOPUS, EThOS, ProQuest, OATD, and open-thesis. Pre-electronic literature of conference papers, scientific articles, books, book chapters, dissertations, and theses were carried out at the university library. Literature search revealed that $H$. natalensis is used as an aphrodisiac, anti-infection, blood purifier, decongestant, for weaning, ethnoveterinary medicine and as herbal medicine for bleeding disorders, gums, nose, colds, gum infections, impotence, menorrhagia, respiratory disorders, toothache, and wounds. Phytochemical compounds identified from the species include essential oils, 3ß-hydroxylup-20(29)-en-28-al, (E)-1-(2',4'-dihyroxy,5'methoxy,3'-methylphenyl)-3-phenylprop-2-en-1-one, (2E)-2-[(2E)-1-hydroxy-3-phenylprop-2-en-1-ylidene]-5-methoxy-6,6-dimethylcyclohex-4-ene1,3-dione, 2',4'-dihydroxy-6'-methoxy-3',5'-dimethylchalcone, 3',4',5'-tri-0-methyl-3,4-methylenedioxy ellagic acid, 3,5,7-trihydroxyflavan, 5-hydroxy7-methoxy-6-methylflavanone, aurentiacin A, betulinic acid, cardamomin, lupenone, lupeol, quercetin, and sitost-4-en-3-one. Pharmacological studies revealed that $H$. natalensis extracts and compounds have antibacterial, antimycobacterial, antifungal, antioxidant, anti-inflammatory, cytotoxicity, and pro-inflammatory activities. Detailed studies are required to establish the efficacy, clinical relevance, safety and mechanisms of action of the plant extracts, and compounds of $H$. natalensis.
\end{abstract}

Keywords: Heteropyxis natalensis, Heteropyxidaceae, Southern Africa, Traditional medicine.

(C) 2019 The Authors. Published by Innovare Academic Sciences Pvt Ltd. This is an open access article under the CC BY license (http://creativecommons. org/licenses/by/4. 0/) DOI: http://dx.doi.org/10.22159/ajpcr.2019.v12i3.29375

\section{INTRODUCTION}

Heteropyxis natalensis Harv. is a tree species which belongs to the Heteropyxidaceae family. Research by Cunningham [1] and Williams et al. [2] revealed that the bark of $H$. natalensis is widely used as herbal medicine in South Africa and therefore, traded in medicinal informal markets in Gauteng and KwaZulu-Natal Provinces in the country. The species is also included in the monographic treatment of "medicinal plants of South Africa" [3], a publication which provides details of how important medicinal plants in the country are utilized. Traditional, complementary, and alternative medicines are popular and widely used in tropical Africa with about $80 \%$ of the people in the continent relying on them for primary health care [4-28]. Mahomoodally [29] argued that the use of herbal medicines is a fundamental component of the African traditional health-care system with traditional healers prescribing herbal medicines because they are the most easily accessible and affordable health resources available to local communities. The same author also argued that Western or allopathic modern medicine is rooted in traditional, complementary, and alternative medicine, and currently, several new pharmaceutical drugs and health-promoting products are being produced and developed from plants traditionally used as herbal medicines [30,31]. Van Wyk [30,31] argued that the essential oils, leaves, and roots of H. natalensis are important in the development of new pharmaceutical and health products in Southern Africa for colds, weaning, nose bleeding, bleeding gums menorrhagia, aromatherapy, and topical products. This is not surprising since $25 \%$ of pharmaceutical drugs and products and $11 \%$ of prescription drugs which are regarded by the World Health Organization as essential to human health are prepared from herbal medicines [32]. It is, therefore, within this context that this study was undertaken aimed at summarizing the phytochemical and ethnopharmacological properties of $H$. natalensis, an important medicinal plant species in Southern Africa.

\section{BOTANICAL PROFILE OF H. NATALENSIS}

The family Heteropyxidaceae consists of three species, H. natalensis, Heteropyxis canescens Oliv., and Heteropyxis dehniae Suess. $[33,34]$. These Heteropyxis species have previously been assigned to families Lythraceae, Myrtaceae, and Rutaceae [35]. H. canescens is confined to Swaziland and KwaZulu-Natal Province in South Africa,

$H$. dehniae is confined to Zimbabwe and the Limpopo Province in South Africa while $H$. natalensis is more widespread, recorded in Botswana, Mozambique, South Africa, Swaziland, and Zimbabwe $[33,34,36-42]$. The genus name "Heteropyxis" is derived from the Greek word "heteros" which means "other" or "distinct" and the Latin word "pyxidatus" which means "a capsule with a box-like lid" [35,43]. The specific name "Natalensis" means "from Natal," which is now KwaZulu-Natal province in South Africa, where the type specimen of the species was collected from [44].

$H$. natalensis is a small deciduous to the semi-deciduous tree of not more than $15 \mathrm{~m}$ in height $[33,35,45]$. The tree consists of a branched trunk, dense leafy branches, and highly aromatic foliage $[33,35]$. The crushed twigs and leaves are strongly aromatic, reminiscent of lavender, hence the English common name of the species, lavender-tree [33]. The bark is pale gray to almost white in color, flaking off on older stems in large pieces. The leaves are simple, alternate, narrowly elliptic, ovate to obovate, shiny dark green above, paler green below, and slightly hairy to hairless when mature, pleasantly aromatic when crushed [33]. The flowers are small, bisexual, occur in branched terminal clusters yellowish green in color. The fruit is a capsule, oval and brownish in color when mature [33]. H. natalensis has been recorded in Bushveld and along forest margins in riverine fringes and often in rocky places, from sea level to an altitude of about $1400 \mathrm{~m}$ above sea level $[33,35,45]$.

\section{MEDICINAL USE OF H. NATALENSIS}

The bark of $H$. natalensis is used as an aphrodisiac [46,47], the bark, leaves, and roots of the species are used as an anti-infection and 
decongestant [3] while leaves are used as blood purifier [46] and for weaning $[3,30,31,48]$ (Table 1$)$. The bark, leaves, roots, and twigs of $H$. natalensis are used as herbal medicines for bleeding disorders, gums, nose, colds, gum infections, impotence, menorrhagia, respiratory disorders, toothache, and wounds [3,30,31,35,46-54]. The leaves of $H$. natalensis are used as ethnoveterinary medicine, mainly as drench for deworming purposes $[3,46]$. Leaves and twigs of $H$. natalensis are used as herbal tea or tisane $[55,56]$, and this practice appears to be popular particularly in South Africa and Swaziland [3,33,35,46,50,51,53,57].

\section{PHYTOCHEMISTRY AND PHARMACOLOGICAL PROPERTIES}

More than 190 essential oils (Table 2) have been identified from the aerial parts of $H$. natalensis. The major essential oils appear to be cadinols $(17.1 \%)$, 1.8-cineole $(0.2-41.2 \%)$, limonene $(1.8-25.4 \%)$, linalool (0.1-42.7\%), myrcene (0.5-10.7\%), (E)-nerolidol $(0.1<-16.3 \%)$, (E)-ocimene $(29.0 \%)$, (E)- $\beta$-ocimene $(0.1<-12.4 \%)$, and $\beta$-pinene (0.05-25.2\%) [58-63]. Previous research demonstrated seasonal and geographical variations in essential oil constituents of $H$. natalensis [58-63]. Previous studies by several researchers showed that essential oils isolated from $H$. natalensis have antibacterial and antifungal properties [60,63-65].

Adesanwo et al. [66] identified (E)-1-(2',4'-dihyroxy,5'-methoxy,3'methylphenyl)-3-phenylprop-2-en-1-one while Shode et al. [67] identified (2E)-2-[(2E)-1-hydroxy-3-phenylprop-2-en-1-ylidene]5-methoxy-6,6-dimethylcyclohex-4-ene-1,3-dione from leaves of H. natalensis. Mohammed et al. [68] identified 2',4'-dihydroxy-6'methoxy-3',5'-dimethylchalcone, 3',4,5'-tri-0-methyl-3,4-methylenedioxy ellagic acid, betulinic acid, lupenone, and lupeolfrom the twigs of $H$. natalensis while the roots yielded 3 3 -hydroxylup-20(29)-en-28-al and sitost-4-en-3-one. Henley-Smith et al. [54] identified cardamomin, aurentiacin A, 5-hydroxy-7-methoxy-6-methylflavanone, quercetin, and 3,5,7-trihydroxyflavan from the leaves and twigs of H. natalensis. The compounds cardamomin, aurentiacin A, quercetin, and 3,5,7-trihydroxyflavan showed antibacterial activities [54].

The extracts and phytochemical compounds of $H$. natalensis showed several pharmacological properties which include antibacterial [52,54,60,63-66,69-72], antimycobacterial [73], antifungal $[52,54,60,63-65,69,72]$, antioxidant $[74,75]$, anti-inflammatory $[75,76]$, cytotoxicity $[54,73,75]$, and pro-inflammatory [54] activities.

\section{Antibacterial activities}

Gundidza et al. [60] evaluated antibacterial activities of the essential oil isolated from $H$. natalensis against 25 bacterial species. The essential oil exhibited activities against all tested microbes showing

Table 1: Medicinal applications of Heteropyxis natalensis in Southern Africa

\begin{tabular}{lll}
\hline Medicinal use & Parts of the plant & References \\
& used & \\
\hline Anti-infection & Bark, leaves, and roots & {$[3]$} \\
Aphrodisiac & Bark & {$[46,47]$} \\
Bleeding disorders & Bark, leaves, and roots & {$[46]$} \\
Bleeding gums & Roots & {$[3,30,35,46,53]$} \\
Blood purifier & Leaves & {$[46]$} \\
Colds & Leaves & {$[3,30,52]$} \\
Decongestant & Bark, leaves, and roots & {$[3]$} \\
Gum infections & Leaves and twigs & {$[51,54]$} \\
Impotence & Bark & {$[47]$} \\
Menorrhagia & Bark, leaves, and roots & {$[3,31,46,48,49,53]$} \\
Nose bleeding & Leaves and roots & {$[3,30,31,35,46,50,53]$} \\
Respiratory disorders & Bark, leaves, and roots & {$[3]$} \\
Toothache & Leaves and twigs & {$[51,54]$} \\
Weaning & Leaves & {$[3,30,31,48]$} \\
Wounds & Bark & {$[50]$} \\
Ethnoveterinary & Leaves used as a & {$[3,46]$} \\
medicine & drench (anthelmintic & \\
& drug) for deworming & \\
\hline
\end{tabular}

good activities against pathogens Escherichia coli, Klebsiella pneumoniae, Staphylococcus aureus, and Moraxella species with lower sensitivities for Pseudomonas aeruginosa [60]. Van Vuuren and Viljoen [64] evaluated the antibacterial activities of the essential oil of $H$. natalensis against $S$. aureus, Staphylococcus epidermidis, Bacillus cereus, Bacillus subtilis, E. coli, P. aeruginosa, Enterococcus faecalis, and K. pneumoniae using the microtiter plate method with ciprofloxacin $(0.01 \mathrm{mg} / \mathrm{ml})$ as a positive control. The essential oil exhibited activities with while minimum inhibitory concentration (MIC) values ranging from $4.5 \mathrm{mg} / \mathrm{mL}$ to $32.0 \mathrm{mg} / \mathrm{mL}$ [64]. Van Vuuren and Viljoen [64] exposed the oil to S. aureus, and the cidal efficacy was plotted over time against the logarithm of viable colonies. The oil showed a rapid cidal effect against the tested pathogen [64]. Van Vuuren et al. [63] evaluated the antibacterial activities of the essential oil of $H$. natalensis against B. cereus, E. faecalis, E. coli, K. pneumoniae, Moraxella catarrhalis, P. aeruginosa, and S. aureus using the microtiter plate method with ciprofloxacin $(0.01 \mathrm{mg} / \mathrm{ml})$ as a positive control. The essential oil exhibited activities with MIC values ranging from $1.0 \mathrm{mg} / \mathrm{ml}$ to $16 \mathrm{mg} / \mathrm{ml}$ [63]. Braithwaite et al. [52] evaluated the antibacterial activities of methanol and acetone leaf extracts, essential oil and smoke fraction of H. natalensis against S. aureus, B. cereus, and K. pneumoniae using the microtiter plate technique with ciprofloxacin as a positive control. The extracts exhibited activities with MIC values ranging from $0.25 \mathrm{mg} / \mathrm{ml}$ to $32.0 \mathrm{mg} / \mathrm{ml}$ [52]. Henley-Smith et al. [69] evaluated the synergistic activities of $H$. natalensis mixed with Melaleuca alternifolia (Maiden and Betche) Cheel, Mentha piperita L., and the green tea extract known as TEAVIGO ${ }^{\text {TM }}$ against Streptococcus mutans and Prevotella intermedia. The mixed extract successfully inhibited the growth of the pathogens [69]. Sharma and Lall [70] evaluated antimicrobial activities of leaf ethanol extracts of H. natalensis against pathogenic bacteria, Propionibacterium acnes using the broth dilution method with tetracycline as a positive control $(0.2 \mathrm{mg} / \mathrm{mL})$. The extracts showed weak activities with MIC value of $250 \mu \mathrm{g} / \mathrm{mL}$ in comparison to the MIC value of $3.1 \mu \mathrm{g} / \mathrm{mL}$ demonstrated by tetracycline, the positive control [70]. Cock and Van Vuuren [71] evaluated antibacterial activities of aqueous and methanol leaf extracts of $H$. natalensis against Alcaligenes faecalis, Aeromonas hydrophila, B. cereus, B. subtilis, Citrobacter freundi, E. coli, K. pneumoniae, Proteus mirabilis, Proteus vulgaris, P. aeruginosa, Pseudomonas fluorescens, Salmonella typhimurium, Serratia marcescens, Shigella sonnei, S. aureus, and S. epidermidis using a modified disk diffusion method with ampicillin $(2 \mu \mathrm{g})$ and chloramphenicol $(10 \mu \mathrm{g})$ as positive controls. Only methanol extract exhibited activities against A. faecalis, A. hydrophilia, B. cereus, B. subtilis, P. mirabilis, P. vulgaris, and S. epidermidis with a zone of inhibition ranging from $6.0 \mathrm{~mm}$ to $8.0 \mathrm{~mm}$, and the MIC values ranged from $525 \mu \mathrm{g} / \mathrm{ml}$ to $6150 \mu \mathrm{g} / \mathrm{ml}$ [71]. Akhalwaya et al. [72] evaluated antibacterial activities of aqueous and dichloromethane:methanol (1:1) leaf and stem extracts of $H$. natalensis against S. mutans, Streptococcus sanguis, Lactobacillus acidophilus, Lactobacillus casei, Porphyromonas gingivalis, and Fusobacterium nucleatum using the microtiter plate dilution assay with ciprofloxacin $(0.1 \mathrm{mg} / \mathrm{mL})$ as a positive control. The extracts exhibited activities with MIC values ranging from $0.21 \mathrm{mg} / \mathrm{mL}$ to $>8.0 \mathrm{mg} / \mathrm{mL}$ [72]. HenleySmith et al. [54] evaluated antibacterial activities of ethanolic leaf and twig extracts of $H$. natalensis against pathogenic oral bacterial organisms, Actinomyces israelii, $P$. intermedia, $S$. mutans, and Lactobacillus paracasei, a commensal bacterium essential in plaque prevention using the microdilution technique with $5 \%$ chlorhexidine gluconate as a positive control. The extracts exhibited activities with MIC values ranging from $0.9 \mathrm{mg} / \mathrm{ml}$ to $12.5 \mathrm{mg} / \mathrm{ml}$ while minimum bactericidal concentration (MBC) values ranged from $3.3 \mathrm{mg} / \mathrm{ml}$ to $>12.5 \mathrm{mg} / \mathrm{ml}$ [54].

Chakravorty et al. [65] evaluated antibacterial activities of essential oils (Z)-3-hexenyl nonanoate, (E)-3-hexenyl nonanoate, hexyl nonanoate, and (Z)-2-hexenylnonanoate isolated from $H$. natalensis against E. coli, P. aeruginosa, Morexella cattarhalis, S. aureus, B. cereus, and Enterococcus facealis using the microdilution method with ciprofloxacin $(0.01 \mathrm{mg} / \mathrm{mL})$ as a positive control. The essential oils showed activities 
Table 2: Essential oils identified from aerial parts of Heteropyxis natalensis

\begin{tabular}{|c|c|c|}
\hline Essential oil (\%) wet weight & Values & References \\
\hline Acetophenone & $0.1<-0.1$ & [63] \\
\hline Agglomerone & 0.4 & [63] \\
\hline Alismol & $0.1-0.7$ & [63] \\
\hline Alloaromadendrene & 0.3 & [63] \\
\hline Amyl isovalerate & $0.1-1.2$ & [63] \\
\hline Aromadendrene & $0.1<$ & [63] \\
\hline Benzaldehyde & $0.1<-0.1$ & [63] \\
\hline Benzyl butanoate & $0.1<-0.3$ & {$[62,63]$} \\
\hline trans- $\alpha$-bergamotol & $0.1<-0.1$ & [63] \\
\hline Borneol & $0.05-0.2$ & [61-63] \\
\hline Bornyl acetate & $0.1-0.2$ & {$[62,63]$} \\
\hline Cadina-1,4-diene (= cubenene) & $0.1<$ & [62] \\
\hline$\alpha$-cadinene & 0.1 & [63] \\
\hline$\delta$-cadinene & $0.05-1.2$ & [61-63] \\
\hline$\gamma$-cadinene & $0.05-0.6$ & [61-63] \\
\hline Cadinol & 17.1 & [59] \\
\hline$\alpha$-cadinol & $0.1<-0.8$ & {$[62,63]$} \\
\hline$T$-cadinol & $0.1-1.4$ & {$[62,63]$} \\
\hline$\alpha$-calacorene & $0.1<-0.1$ & {$[62,63]$} \\
\hline cis-calamenene & $0.1<-0.6$ & {$[62,63]$} \\
\hline Camphene & $0.1<-0.1$ & {$[62,63]$} \\
\hline Camphor & $0.05-0.1$ & [61] \\
\hline Carvacrol & $0.1<$ & [62] \\
\hline Carvone hydrate (= aralone) & 0.2 & [63] \\
\hline Caryophylla-2 (12),6-dien-5 $\alpha$-ol (= caryophyllenoli) & $0.1<-0.4$ & {$[62,63]$} \\
\hline Caryophylla-2 (12),6-dien-5 $\beta$-ol (= caryophyllenol ii) & $0.1-0.5$ & {$[62,63]$} \\
\hline Caryophylla-2 (12),6 (13)-dien-5 $\beta$-ol (= caryophylladienoli) & $0.1<$ & {$[62,63]$} \\
\hline Caryophylla-2 (12),6 (13)-dien-5 $\alpha$-ol (= caryophylladienol ii) & $0.1-0.4$ & {$[62,63]$} \\
\hline cis-carveol & $0.1<-0.2$ & [63] \\
\hline trans-carveol & $0.1<-0.5$ & {$[62,63]$} \\
\hline Carvone & $0.1<-0.5$ & {$[62,63]$} \\
\hline$\beta$-caryophyllene & $0.05-1.9$ & {$[62,63]$} \\
\hline$p$-caryophyllene & 3.3 & [58] \\
\hline Caryophyllene oxide & $0.05-9.9$ & {$[59,61-63]$} \\
\hline Cinnamyl acetate & $0.1<-7.6$ & {$[59,63]$} \\
\hline 1,8-cineole & $0.2-41.2$ & [58-63] \\
\hline Clovenol & $0.1<-0.1$ & {$[62,63]$} \\
\hline$\alpha$-copaene & $0.1<-0.1$ & {$[62,63]$} \\
\hline$\beta$-copaene & $0.1<-0.2$ & [63] \\
\hline$\alpha$-cubebene & 0.1 & [63] \\
\hline Cubenol & $0.1<-0.5$ & {$[62,63]$} \\
\hline epi-cubenol & 4.5 & [59] \\
\hline 1-epi-cubenol & $0.1-0.2$ & {$[62,63]$} \\
\hline 6-epi-cubenol & $0.1<-0.3$ & {$[62,63]$} \\
\hline$p$-cymen-8-ol & $0.05-0.5$ & [61-63] \\
\hline$p$-cymene & $0.1-5.8$ & {$[61-63]$} \\
\hline Decanal & 0.1 & [63] \\
\hline 4,4-dimethyl but-2-enolide & 0.1 & {$[63]$} \\
\hline 3,7-dimethyloct-1-en-3,6,7-triol & 0.5 & [63] \\
\hline 2,6-dimethyl-3(E),5(E),7-octatriene-2-ol & $0.1<-0.1$ & [63] \\
\hline 3,7-dimethyl-1,7-octadien-3,6-diol & 3.4 & [63] \\
\hline$\alpha, p$-dimethylstyrene & $0.1<$ & {$[62]$} \\
\hline Eicosane & $0.1<$ & [62] \\
\hline$\beta$-elemene & 0.1 & [63] \\
\hline Elemol & 0.4 & [63] \\
\hline (E, E)-10,11-epoxyfarnesyl acetate & 0.4 & [63] \\
\hline 1,5-epoxy-salvial (4) 14-ene & 0.1 & [62] \\
\hline cis-1,2-epoxy-terpin-4-ol & $0.1<-0.2$ & [63] \\
\hline Eremoligenol & $0.1-1.7$ & {$[62,63]$} \\
\hline Eudesma-4 (15),7-dien-1- $\beta$-ol & $0.1<-0.5$ & {$[62,63]$} \\
\hline$\alpha$-eudesmol & $0.4-7.5$ & {$[62,63]$} \\
\hline$\beta$-eudesmol & $0.8-3.1$ & [63] \\
\hline$\gamma$-eudesmol & $0.2-5.2$ & {$[62,63]$} \\
\hline$(E, E)$ - $\alpha$-farnesene & $0.1<$ & {$[62,63]$} \\
\hline (2E,6E)-farnesol & $0.1-0.5$ & {$[62,63]$} \\
\hline (2E,6E)-farnesyl acetate & $0.1<$ & {$[62]$} \\
\hline Fenchyl acetate & $0.1<-0.1$ & {$[62,63]$} \\
\hline Fenchyl alcohol & $0.1<-0.2$ & [63] \\
\hline Geraniol & $0.1<-0.3$ & {$[62,63]$} \\
\hline Geranyl acetate & $0.05-0.2$ & [61-63] \\
\hline
\end{tabular}


Table 2: (Continued)

\begin{tabular}{|c|c|c|}
\hline Essential oil (\%) wet weight & Values & References \\
\hline Geranyl butyrate & $0.1<-0.2$ & {$[62,63]$} \\
\hline Gleenol & $0.1<$ & {$[62,63]$} \\
\hline Globulol & $0.1-0.8$ & {$[62,63]$} \\
\hline$\alpha$-guaiol & 0.5 & {$[63]$} \\
\hline Guaiyl acetate & 0.2 & [63] \\
\hline 4,6-guaiadiene $(=\gamma$-guaiene $)$ & $0.1<$ & [63] \\
\hline Heneicosane & $0.1<$ & [63] \\
\hline$\gamma$-heptalactone & 1.1 & [63] \\
\hline cis-p-mentha-1 (7),8-dien-2-ol (= cis-2-hydroxy pseudolimonene) & 0.1 & [63] \\
\hline Hexadecanol & $0.1<$ & [62] \\
\hline 2-heptyl acetate & $0.1-0.2$ & {$[62,63]$} \\
\hline (Z)-3-hexen-1-yl benzoate & 0.1 & [63] \\
\hline (Z)-3-hexenyl acetate & 0.1 & [62] \\
\hline (Z)-3-hexenol & $0.1<-0.4$ & [63] \\
\hline (E)-2-hexenyl butyrate & $0.1<-0.2$ & {$[62,63]$} \\
\hline (Z)-3-hexenyl butyrate & $0.1-0.2$ & [63] \\
\hline (Z)-3-hexenyl nonanoate & 16.0 & [63] \\
\hline Hinesol & $0.1<$ & {$[62]$} \\
\hline Hotrienol & 0.3 & [63] \\
\hline$\alpha$-humulene & $0.05-0.8$ & {$[61-63]$} \\
\hline Humulene epoxide-i & $0.1<-0.1$ & {$[62,63]$} \\
\hline Humulene epoxide-ii & $0.2-1.6$ & {$[62,63]$} \\
\hline Humulene epoxide-iii & $0.1<$ & [62] \\
\hline 10-hydroxy calamenene & $0.1-0.4$ & [63] \\
\hline trans-2-hydroxy-1,8-cineole & 0.1 & [63] \\
\hline (E)- $\beta$-ionone & 0.1 & [63] \\
\hline Isocaryophyllene oxide & $0.1<-0.5$ & [63] \\
\hline cis-jasmone & $0.1<-0.1$ & [63] \\
\hline Kaur-16-ene & 0.2 & [63] \\
\hline Limonene & $1.8-25.4$ & [58-63] \\
\hline cis-1,2-limonene epoxide & $0.1<-0.3$ & [63] \\
\hline trans-1,2-limonene epoxide & 0.2 & [63] \\
\hline 8,9-limonene epoxide-i & $0.1<$ & [63] \\
\hline Linalool & $0.1-42.7$ & [58-63] \\
\hline cis-linalool oxide (furanoid) & $0.1<-8.0$ & [63] \\
\hline cis-linalool oxide (pyranoid) & $0.1-0.9$ & {$[61,63]$} \\
\hline trans-linalool oxide (pyranoid) & $0.05-0.5$ & {$[61,63]$} \\
\hline trans-linalool oxide (furanoid) & $0.1<-8.8$ & [63] \\
\hline Linalyl acetate & $0.05-0.5$ & {$[61,63]$} \\
\hline trans- $p$-menth-2-en-1-ol & $0.1<-0.1$ & {$[62,63]$} \\
\hline$p$-mentha-1,7 (8)-diene (= pseudolimonene) & $0.1<-7.1$ & [63] \\
\hline Methyl-4-(4'-methyl-3'-pentenyl)-3-cyclohexenyl ketone & 0.1 & {$[63]$} \\
\hline 2-methylbutyl acetate & 0.1 & [63] \\
\hline 2-methylbutyl butyrate & $0.1<-0.4$ & {$[62,63]$} \\
\hline 3-methyl butyl hexanoate (= isoamyl hexanoate) & 0.1 & [63] \\
\hline cis-p-menth-2-en-1-ol & $0.1<-1.0$ & {$[61,63]$} \\
\hline cis- $p$-menth-3-en-1,2-diol & $0.1-0.5$ & [63] \\
\hline trans-p-mentha-2,8-dien-1-ol & $0.1<-0.2$ & [63] \\
\hline cis-p-mentha-2,8-dien-1-ol & 0.1 & [63] \\
\hline cis- $p$-mentha-1 (7),8-dien-2-ol (= cis-2-hydroxy pseudolimonene) & $0.1<$ & [63] \\
\hline trans-p-mentha-1 (7),8-dien-2-ol (= trans-2-hydroxy pseudolimonene) & $0.1<$ & {$[62,63]$} \\
\hline$p$-mentha-1,8-dien-4-ol(= limonen-4-ol $)$ & $0.1<-0.1$ & [63] \\
\hline$p$-methyl acetophenone & $0.1<$ & [63] \\
\hline Methyl salicylate & $0.1<$ & [63] \\
\hline 4-methyl-4-vinyl butyrolactone & 5.3 & [63] \\
\hline 3-methyl-2-butenyl butyrate & $0.2-1.1$ & [63] \\
\hline 3-methyl-3-butenyl isovalerate & 0.1 & [62] \\
\hline 3-methyl-2-butenyl hexanoate & $0.1<-0.1$ & [63] \\
\hline 6-methyl-3,5-heptadien-2-one & $0.1-0.2$ & [63] \\
\hline$\gamma$-muurolene & 0.3 & {$[62,63]$} \\
\hline$\alpha$-muurolene & $0.1-0.3$ & [63] \\
\hline$T$-muurolol & $0.1<-0.3$ & {$[62,63]$} \\
\hline Myrtenal & $0.1-0.3$ & [63] \\
\hline Myrtenol & $0.1-0.3$ & [63] \\
\hline Myrtenyl acetate & $0.1<$ & [63] \\
\hline Myrcene & $0.5-10.7$ & {$[59-63]$} \\
\hline Neointermedeol & $0.1<-0.6$ & {$[62,63]$} \\
\hline (E)-nerolidol & $0.1<-16.3$ & {$[59,62,63]$} \\
\hline Nerol & 0.1 & [63] \\
\hline Neryl acetate & $0.1<$ & {$[62,63]$} \\
\hline
\end{tabular}


Table 2: (Continued)

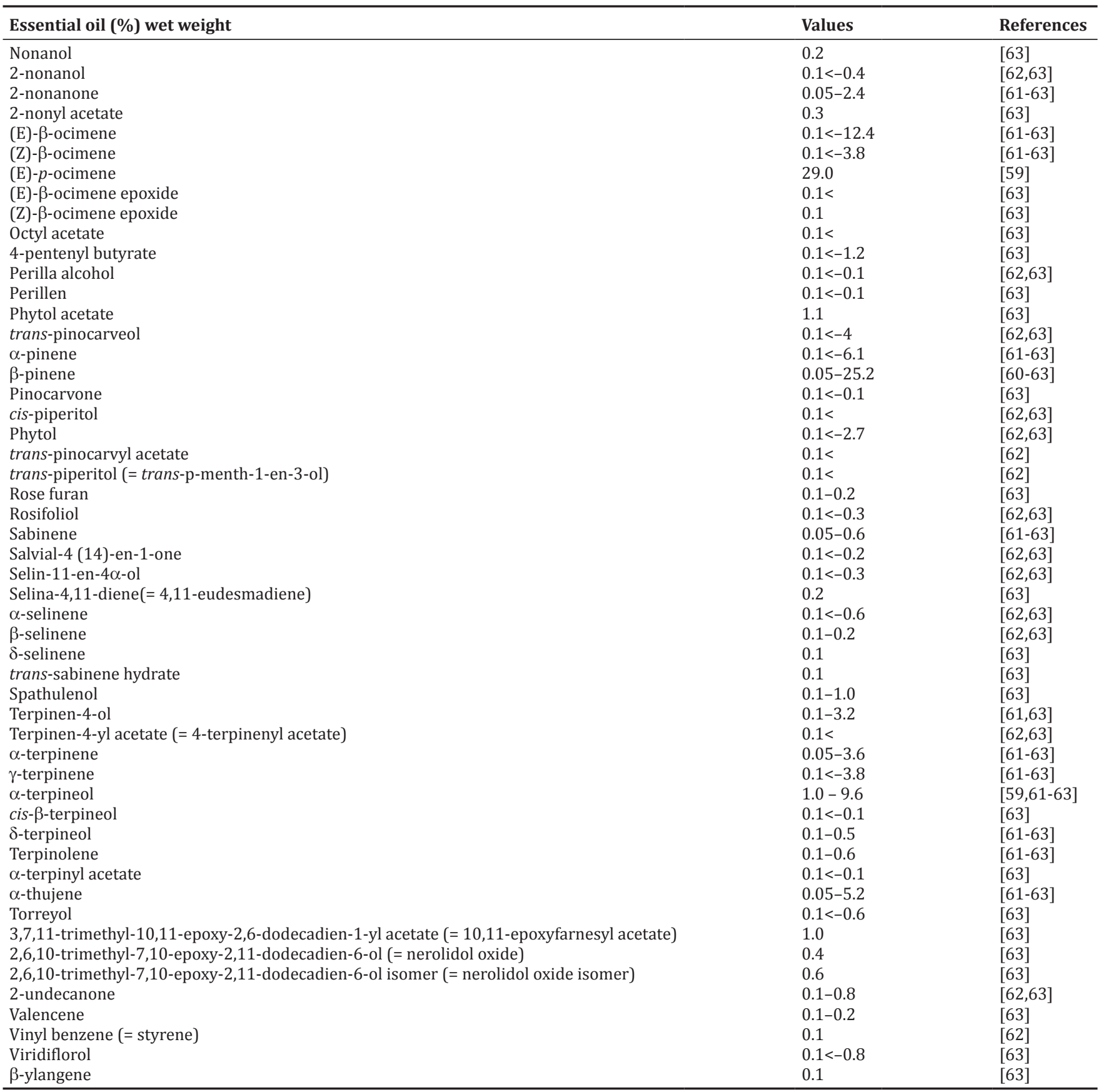

with MIC values ranging from $0.5 \mathrm{mg} / \mathrm{mL}$ to $3.5 \mathrm{mg} / \mathrm{mL}$ [65]. HenleySmith et al. [54] evaluated antibacterial activities of the compounds cardamomin, aurentiacin A, 5-hydroxy-7-methoxy-6-methylflavanone, quercetin, and 3,5,7-trihydroxyflavan isolated from $H$. natalensis against A. israelii using the microdilution technique with $5 \%$ chlorhexidine gluconate as a positive control. Only cardamomin, aurentiacin A, quercetin, and 3,5,7-trihydroxyflavan were active against the pathogen with MIC values ranging from $0.06 \mathrm{mg} / \mathrm{ml}$ to $>1 \mathrm{mg} / \mathrm{ml}$, while MBC values for aurentiacin A and quercetin were $0.06 \mathrm{mg} / \mathrm{ml}$ to $1 \mathrm{mg} / \mathrm{ml}$, respectively [54]. An enzymatic bioanalysis of lactic and acetic acid production from S. mutans and L. paracasei was carried out after 24-h incubation with the ethanolic leaf and twig extract of $H$. natalensis. A reduction in the acid production from each bacterium was observed on exposure to the extract, and this consequently increased the $\mathrm{pH}$, which could possibly reduce the demineralization of enamel which may help prevent the formation of dental caries [54].

\section{Antimycobacterial activities}

Dzoyem et al. [73] evaluated the antimycobacterial activities of acetone leaf extracts of $H$. natalensis against Mycobacterium smegmatis, Mycobacterium aurum, Mycobacterium fortuitum, and Mycobacterium tuberculosis using a tetrazolium violet based broth microdilution method with isoniazid $(\mu \mathrm{g} / \mathrm{mL})$ and rifampicin $(\mu \mathrm{g} / \mathrm{mL})$ as positive controls. The extracts exhibited activities with MIC values ranging from $0.08 \mathrm{mg} / \mathrm{mL}$ to $0.62 \mathrm{mg} / \mathrm{mL}$ and the total activities ranged from $147.2 \mathrm{~mL} / \mathrm{g}$ to $1150 \mathrm{~mL} / \mathrm{g}$ [73]

\section{Antifungal activities}

Gundidza et al. [60] evaluated antifungal activities of the essential oil isolated from H. natalensis against Aspergillus flavus, Aspergillus niger, Aspergillus ochraceus, and Aspergillus parasiticus. The essential oil exhibited activities against all tested microbes [60]. Van Vuuren and Viljoen [64] evaluated the antifungal activities of the essential oil of 
H. natalensis against Candida albicans and Cryptococcus neoformans using the microtiter plate method with amphotericin B $(0.01 \mathrm{mg} / \mathrm{ml})$ as a positive control. The essential oil exhibited activities with MIC value of $4.5 \mathrm{mg} / \mathrm{mL}$ and $5.7 \mathrm{mg} / \mathrm{mL}$ against C. albicans and C. neoformans, respectively [64]. To demonstrate the time-kill efficacy of the essential oil of H. nalalensis, Van Vuuren and Viljoen [64] exposed the essential oil to $C$. albicans, and cidal efficacy plotted over time against the logarithm of viable colonies. The oil showed a rapid cidal effect against the tested pathogens [64]. Van Vuuren et al. [63] evaluated antifungal activities of the essential oil of $H$. natalensis collected from various geographical regions in South Africa against $C$. neoformans using the microtiter plate method with amphotericin $B(0.01 \mathrm{mg} / \mathrm{ml})$ as a positive control. The essential oil exhibited activities with MIC values ranging from $0.5 \mathrm{mg} / \mathrm{ml}$ to $3.0 \mathrm{mg} / \mathrm{ml}$ [63]. Braithwaite et al. [52] evaluated the antifungal activities of methanol and acetone leaf extracts, essential oil and a smoke fraction of $H$. natalensis against $C$. neoformans using the microtiter plate technique with amphotericin $\mathrm{B}$ as a positive control. The extracts exhibited activities with MIC values ranging from $0.93 \mathrm{mg} / \mathrm{ml}$ to $8.0 \mathrm{mg} / \mathrm{ml}$ [52]. Henley-Smith et al. [69] evaluated the synergistic activities of $H$. natalensis mixed with M. alternifolia, M. piperita and the green tea extract known as TEAVIGO ${ }^{\mathrm{TM}}$ against C. albicans and the mixed extract successfully inhibited the growth of the pathogen [69]. Akhalwaya et al. [72] evaluated antifungal activities of aqueous and dichloromethane:methanol (1:1) leaf and stem extracts of $H$. natalensis against C. albicans, Candida glabrata, and Candida krusei using the microtiter plate dilution assay with amphotericin B $(0.01 \mathrm{mg} / \mathrm{mL})$ as a positive control. The extracts exhibited activities with MIC values ranging from $0.25 \mathrm{mg} / \mathrm{mL}$ to $>8.0 \mathrm{mg} / \mathrm{mL}$ [72]. Henley-Smith et al. [54] evaluated antifungal activities of ethanolic leaf and twig extracts of $H$. natalensis against pathogenic oral fungal species, $C$. albicans and polyene and azole-resistant $C$. albicans using the microdilution technique with amphotericin $\mathrm{B}$ as the positive control. The extracts exhibited activities with MIC value of $8.3 \mathrm{mg} / \mathrm{ml}$ and $12.5 \mathrm{mg} / \mathrm{ml}$ against $C$. albicans and polyene and azole-resistant C. albicans, respectively, while minimum fungicidal concentration values were $10.4 \mathrm{mg} / \mathrm{ml}$ and $>12.5 \mathrm{mg} / \mathrm{ml}$ against $C$. albicans and polyene and azole-resistant $C$. albicans, respectively [54]. Chakravorty et al. [65] evaluated antifungal activities of essential oils (Z)-3-hexenyl nonanoate, (E)-3-hexenyl nonanoate, hexyl nonanoate, and (Z)-2hexenylnonanoate isolated from $H$. natalensis against $C$. albicans and C. neoformans using the microdilution method with amphotericin $B$ $(0.01 \mathrm{mg} / \mathrm{mL})$ as a positive control. The essential oils showed activities with MIC values ranging from $0.5 \mathrm{mg} / \mathrm{mL}$ to $1.5 \mathrm{mg} / \mathrm{mL}$ [65].

\section{Antioxidant activities}

Muchuweti et al. [74] evaluated the antioxidant activities of ethanol leaf and stem extracts of $H$. natalensis using the 2,2-diphenyl-1-picrylhydrazyl hydrate (DPPH) radical scavenging assay. The percentage inhibition exhibited by the extracts was $29.7 \%$ for the standard $\beta$-carotene, and the amount of total phenolics was $0.096 \pm 0.02$ milligrams tannic acid per $100 \mathrm{mg}$ of plant sample [74]. Mzindle [75] evaluated antioxidant activities of aqueous and methanol extracts of $H$. natalensis using the DPPH radical scavenging assay with rutin as a positive control. The extracts showed free radical scavenging abilities ranging from 42.9 $\pm 2.8 \%$ to $101.1 \pm 2.1 \%$, while rutin exhibited free radical scavenging abilities ranging from $27.4 \pm 1.4 \%$ to $95.3 \pm 0.5 \%$ [75].

\section{Anti-inflammatory activities}

Frum and Viljoen [76] evaluated anti-inflammatory activities of the essential oils 1.8-cineole, linalool, limonene, and $\beta$-pinene isolated from $H$. natalensis using the 5-lipoxygenase inhibitory assay. All oils tested exhibited promising 5-lipoxygenase inhibitory activities with half maximal $\mathrm{IC}_{50}$ value of $46.6 \mathrm{ppm}$ [76]. Mzindle [75] evaluated anti-inflammatory activities of aqueous and methanol leaf extracts of $H$. natalensis using the lipoxygenase inhibitor screening assay with nordihydroguaiaretic acid as a positive control. The aqueous and methanol extracts inhibited lipoxygenase enzyme by $101.6 \% \pm 3.8 \%$ and $58.2 \pm 12.3$, respectively, which was lower than $122 \%$ and $129 \%$ inhibition demonstrated by nordihydroguaiaretic acid, the control [75].
Mzindle [74] also evaluated the wound healing activities of aqueous and methanol extracts of $H$. natalensis using the scratch wound assay. The migration rate of the extracts ranged from $24.9 \% \pm$ $3.5 \%$ to $38.7 \% \pm 2.7 \%$ when compared to the untreated cells with a percentage migration rate of $24 \%$ [75].

\section{Cytotoxicity activities}

Dzoyem et al. [73] evaluated the cytotoxicity activities acetone of leaf extracts of $H$. natalensis using the colorimetric tetrazoliumbased 3-(4,5-dimethylthiazol-2-yl)-2,5-diphenyltetrazolium bromide (MTT) assay on Vero monkey kidney cells with doxorubicin as a positive control. Compared to doxorubicin which exhibited median lethal concentration $\left(\mathrm{LC}_{50}\right)$ value of $4.51 \mu \mathrm{g} / \mathrm{mL}$, the extract could be considered as relatively safe with $\mathrm{LC}_{50}$ value of $264.1 \mu \mathrm{g} / \mathrm{mL}$ with selectivity index (SI) value of 0.4-3.3 [73]. Henley-Smith et al. [54] used human monocyte (U937), kidney epithelial cells of the African green monkey (Vero) and human laryngeal epidermoid carcinoma (HEp-2) cells to assess cytotoxicity activities of ethanolic leaf and twig extract of $H$. natalensis using the XTT (Sodium 3'-[1-(phenyl amino-carbonyl)3,4-tetrazolim]-bis-[4 methoxy-6-nitro] benzene sulfonic acid hydrate) assay as described by Zheng et al. [77]. The extract showed a IC ${ }_{50}$ value of $35.6 \mu \mathrm{g} / \mathrm{ml}, 147.0 \mu \mathrm{g} / \mathrm{ml}$, and $33.7 \mu \mathrm{g} / \mathrm{ml}$ on macrophage U937 cells, Vero, and HEp-2 cells, respectively. Therefore, on Vero cells, the extract might be potentially harmful, but on HEp-2 and U937 cells, the extract could be potentially toxic. Mzindle [75] evaluated the cytotoxicity of aqueous and methanol leaf extracts of H. natalensis using MTT assay on 3T3 NIH fibroblast cells by treating them with various concentrations of the extracts. The extracts exhibited $>100 \%$ viability, indicating that the extracts were not toxic to the cells [75]

\section{Pro-inflammatory activities}

Henley-Smith et al. [54] evaluated the pro-inflammatory activities of ethanolic leaf and twig extracts of $H$. natalensis using $C$. albicans and $P$. intermedia. A significant reduction of interleukin-8 production by macrophage cells was observed when exposed to the extract. It is possible that $H$. natalensis can prevent excessive tissue damage in periodontal diseases through its reduction of inflammation [54].

\section{CONCLUSION}

H. natalensis is an important herbal medicine in Southern Africa, and significant breakthrough has been made in the past 40 years elucidating the phytochemical and pharmacological properties of the species. However, there are still some research gaps regarding correlating the medicinal uses of $H$. natalensis with its chemical compounds and associated pharmacological properties of the compounds and extracts of the species. Detailed studies on the pharmacokinetics, in vivo and clinical research involving compounds isolated from the species and its extracts, are required.

\section{ACKNOWLEDGMENTS}

The author would like to express his gratitude to the National Research Foundation, South Africa and Govan Mbeki Research and Development Centre, University of Fort Hare for financial support to conduct this study.

\section{AUTHOR'S CONTRIBUTIONS}

The author declares that this work was done by the author named in this article.

\section{CONFLICTS OF INTEREST}

No conflicts of interest are associated with this work.

\section{REFERENCES}

1. Cunningham AB. African Medicinal Plants: Setting Priorities at the Interface BetweenConservation and Primary Health Care. Paris: People and Plants Working Paper 1, UNESCO; 1993.

2. Williams VL, Balkwill K, Witkowski ET, A lexicon of plants traded in 
the Witwatersrand umuthi shops, South Africa. Bothalia 2001;31:71-98.

3. Van Wyk BE, Oudtshoorn BV, Gericke N. Medicinal Plants of South Africa. Pretoria: Briza Publications; 2013.

4. Sofowora A. Medicinal Plants and Traditional Medicine in Africa. Chichester: Wiley; 1982.

5. Farnsworth NR, Akerele OA, Soejarto DD, Guo Z. Medicinal plants in therapy. Bull World Health Organ 1985;63:965-81.

6. Gelfand M, Mavi S, Drummond RB, Ndemera B. The Traditional Medicine Practitioner in Zimbabwe: His Principles of Practice and Pharmacopoeia. Gweru: Mambo Press; 1985.

7. Oliver-Bever B. Medicinal Plants of Tropical West Africa. Cambridge: Cambridge University Press; 1986.

8. Hedberg I, Staugård F. Traditional Medicine in Botswana: Traditional Medicinal Plants. Gaborone: Ipelegeng Publishers; 1989.

9. Kokwaro JO. Medicinal Plants of East Africa. Nairobi: East Africa Literature Bureau; 1993.

10. Burkill HM. The Useful Plants of West Tropical Africa. London: Royal Botanic Gardens, Kew; 1995.

11. Hostettmann K, Marston A, Ndjoko K, Wolfender JL. The potential of African medicinal plants as a source of drugs. Curr Org Chem 2000;4:973-1010.

12. Neuwinger HD. African Traditional Medicine: A Dictionary of Plant use and Applications. Stuttagart: Medpharm Scientific Publishers; 2000

13. Arnold TH, Prentice GA, Hawker LC, Snyman EE, Tomalin M, Crouch NR, et al. Medicinal and Magical Plants of Southern Africa: An Annotated Checklist. Pretoria: Strelitzia 13, National Botanical Institute; 2002

14. World Health Organization. Traditional, Complementary and Integrative Medicine; 2017. Available from: http://www.who.int/ traditional-complementary-integrative-medicine/about/en

15. World Health Organization. WHO Traditional Medicine Strategy 2002-2005; 2002. Available from: http://www.wpro.who.int/health technology/book who traditional medicine strategy 2002 2005.pdf.

16. Gurib-Fakim A, Brendler T. Medicinal and Aromatic Plants of Indian Ocean Islands: Madagascar, Comores, Seychelles and Mascarenes. Stuttgart: Medpharm Scientific Publishers; 2004.

17. Elujoba A, Odeleye O, Ogunyemi C. Traditional medicine development for medicinal and dental primary health care delivery system in Africa. Afr J Trad Complement Altern Med 2005;2:46-61.

18. Schmelzer GH, Gurib-Fakim A. The Plant Resources of Tropical Africa 11(1): Medicinal Plants 1. Wageningen: Plant Resources of Tropical Africa; 2013.

19. Maroyi A. Ethnobotanical study of medicinal plants used by people in Nhema communal area, Zimbabwe. J Ethnopharmacol 2011;136:347-54.

20. Maroyi A. Garden plants in Zimbabwe: Their ethnomedicinal uses and reported toxicity. Ethnobot Res Appl 2012;10:45-57.

21. Maroyi A. Traditional use of medicinal plants in south-central Zimbabwe: Review and perspectives. J Ethnobiol Ethnomed 2013;9:31.

22. Dzoyem JP, Tshikalange E. Medicinal Plant Research in Africa. Oxford: Elsevier; 2013

23. Iwu M. Handbook of African Medicinal Plants. Boca Raton: CRC Press; 2014.

24. Maroyi A, Mosina GK. Medicinal plants and traditional practices in peri-urban domestic gardens of the Limpopo Province, South Africa. Indian J Indian Knowl 2014;13:665-72.

25. Maroyi A, Cheikhyoussef A. A comparative study of medicinal plants used in rural areas of Namibia and Zimbabwe. Indian J Indian Knowl 2015;14:401-6.

26. Neffati M, Najjaa H, Mathé A. Medicinal and Aromatic Plants of the World. Vol. 3. Africa: Springer; 2017

27. Maroyi A. Eucleacrispa: Review of its botany, ethnomedicinal uses and pharmacological properties. Asian J Pharm Clin Res 2018;11: 5-9.

28. Maroyi A. Dicoma anomala Sond: A review of its botany, ethnomedicine, phytochemistry and pharmacology. Asian J Pharm Clin Res 2018;11:70-7.

29. Mahomoodally MF. Traditional medicines in Africa: An appraisal of ten potent African medicinal plants. Evid Based Complement Altern Med 2013;2013:14

30. Van Wyk BE. A broad review of commercially important southern African medicinal plants. J Ethnopharmacol 2008;119:342-55.

31. Van Wyk BE. The potential of South African plants in the development of new medicinal products. S Afr J Bot 2011;77:812-29.

32. Rates SM. Plants as source of drugs. Toxicon 2001;39:603-13.

33. Palgrave MC. Keith Coates Palgrave Trees of southern Africa. $3^{\text {rd }}$ ed. Cape Town: Struik Publishers (Pty) Ltd.; 2002.

34. Germishuizen G, Meyer NL, Steenkamp Y, Keith MA. A Checklist of South African Plants. Pretoria: Southern African Botanical Diversity
Network Report No. 41, SABONET; 2006.

35. Palmer E, Pitman P. Trees for Southern Africa covering all Known Indigenous Species in Republic of South Africa, South West Africa, Botswana, Lesotho and Swaziland. Cape Town: A.A. Balkema; 1972.

36. Sibanda S, Chigwada G, Poole M, Gwebu ET, Noletto JA, Schmidt JM, et al. Composition and bioactivity of the leaf essential oil of Heteropyxis dehniae from Zimbabwe. J Ethnopharmacol 2004;92:107-11

37. Drummond RB. A list of trees, shrubs and woody climbers indigenous or naturalised in Rhodesia. Kirkia 1975;10:229-86.

38. Setshogo MP. Preliminary Checklist of the Plants of Botswana. Pretoria: SABONET Report No. 37; 2005.

39. Strugnell AM. A checklist of the spermatophytes of Mount Mulanje, Malawi. Scripta Bot Belgica 2006;34:5-194.

40. Hyde MA, Wursten BT, Ballings P, Palgrave CM. Flora of Botswana: Species Information: Heteropyxis natalensis; 2018. Available from: https://www.botswanaflora.com/speciesdata/species.php?species id=142490. [Last accessed on 2018 Aug 10].

41. Hyde MA, Wursten BT, Ballings P, Palgrave CM. Flora of Mozambique: Species Information: Heteropyxis natalensis; 2018. Available from: https://www.mozambiqueflora.com/speciesdata/species.php?species $\mathrm{id}=142490$. [Last accessed on 2018 Aug 10].

42. Hyde MA, Wursten BT, Ballings P, Palgrave CM. Flora of Zimbabwe: Species Information: Heteropyxis natalensis; 2018. Available from: https://www.zimbabweflora.co.zw/speciesdata/species.php?species id $=142490$. [Last accessed on 2018 Aug 10].

43. Venter F, Venter JA. Making the Most of Indigenous Trees. Pretoria: Briza publications; 2002

44. Fernandes A. Heteropyxidaceae. In: Launert E, editor. London: Flora Zambesiaca Managing Committee; 1978. p. 212-5.

45. Van Wyk B, Van Wyk P. Field Guide to Trees of Southern Africa. Cape Town: Struik Publishers; 1997.

46. Watt JM, Breyer-Brandwijk MG. The Medicinal and Poisonous Plants of Southern and Eastern Africa. London: E and S Livingstone Ltd; 1962.

47. Hutchings A, Scott AH, Lewis G, Cunningham AB. Zulu Medicinal Plants: An Inventory. Pietermaritzburg: University of Natal Press; 1996.

48. Mabogo DE. The Ethnobotany of the Vhavenda. MSc Dissertation, Pretoria: University of Pretoria; 1990

49. Arnold HJ, Gulumian M. Pharmacopoeia of traditional medicine in Venda. J Ethnopharmacol 1984;12:35-74

50. Long C. Swaziland's Flora: SiSwati Names and Uses. Swaziland National Trust Commission; 2005. Available from: http://www.sntc. org.sz/index.asp. [Last accessed on 2018 Jul 29].

51. Van Wyk BE, Gericke N. Peoples Plants: A Guide to Useful Plants of Southern Africa. Pretoria: Briza Publications; 2007.

52. Braithwaite M, Van Vuuren SF, Viljoen AM. Validation of smoke inhalation therapy to treat microbial infections. J Ethnopharmacol 2008;119:501-6.

53. Van Vuuren SF, Viljoen AM. Indigenous South African medicinal plants. Part 10. Heteropyxis natalensis ('lavender tree'). SA Pharm J 2008;75:46

54. Henley-Smith CJ, Botha FS, Hussein AA, Nkomo M, Meyer D, Lall N. Biological activities of Heteropyxis natalensis against micro-organisms involved in oral infections. Front Pharmacol 2018;9:291.

55. Sõukand R, Kalle R. Where does the border lie: Locally grown plants used for making tea for recreation and/or healing, 1970s-1990s Estonia. J Ethnopharmacol 2013;150:162-74.

56. Maroyi A. Lippia javanica (Burm. f.) Spreng: Traditional and commercial uses, phytochemical and pharmacological significance. Evid Based Complement Altern Med 2017;2017:34

57. Gerstner J. A preliminary checklist of Zulu names of plants with short notes. Bantu Stud 1939;13:1-149.

58. Gouveia AP, Figueredo MG, Silva AM, De Gouveia AJ. Essential oil from Heteropyxis natalensis. Rev Port Quim 1972;14:230-8.

59. Weyerstahl P, Christiansen C, Gundidza M, Mavi S. Constituents of the essential oil of Heteropyxis natalensis. J Essent Oil Res 1992;4:439-45.

60. Gundidza M, Deans SG, Kennedy AI, Mavi S, Waterman PG, Gray AI. The essential oil of Heteropyxis natalensis Harv: Its antimicrobial activities and phytoconstituents. J Sci Food Agr1993;63:361-4.

61. Chagonda LS, Makanda CD, Chalchat JC. Essential oils of cultivated Heteropyxis natalensis (Harv.) and cultivated Heteromorpha Trifoliata (Wendl.) Eckl. and Zey. from Zimbabwe. J Essent Oil Res 2000;12:317-21.

62. Frum Y. In Vitro 5-lipoxygenase and Anti-oxidant Activities of South African Medicinal Plants Commonly Used Topically for Skin Diseases. MSc Dissertation. Johannesburg: University of the Witwatersrand; 2006.

63. Van Vuuren SF, Viljoen AM, Özek T, Demirci B, Başer KH. Seasonal and geographical variation of Heteropyxis natalensis essential oil and the 
effect thereof on the antimicrobial activity. S Afr J Bot 2007:73: 441-8.

64. Van Vuuren SF, Viljoen AM. A comparative investigation of the antimicrobial properties of indigenous South African aromatic plants with popular commercially available essential oils. J Essent Oil Res 2006; 18:66-71

65. Chakravorty S, Rayner MK, De Koning CB, Van VuurenSF, Van Otterlo WA. Synthesis and antimicrobial activity of the essential oil compounds (E)-and (Z)-3-hexenyl nonanoate and two analogues. S Afr J Chem 2012:65:202-5.

66. Adesanwo JK, Shode FO, Aiyelaagbe O, Oyede RT, Baijnath H. Isolation and characterization of a new chalcone from the leaves of Heteropyxis natalensis. Int J Med Sci 2009;1:28-32.

67. Mohammed AM, Coombes PH, Crouch NR, Mulholland DC. Nonvolatile isolates of two Heteropyxis species: A first chemotaxonomic assessment of subfamily psiloxyloideae (Myrtaceae). Biochem Syst Ecol 2009;37:241-3.

68. Shode FO, Oyede RT, Adesanwo JK, Baijnath H. Extractives from Heteropyxis natalensis. In Proceedings of the $11^{\text {th }}$ NAPRECA Symposium. Antananarivo; 2005. p. 187-92.

69. Henley-Smith CJ, Steffens FE, Botha FS, Lall N. Predicting the influence of multiple components on microbial inhibition using a logistic response model: A novel approach. BMC Complement Altern Med 2014:14:190.

70. Sharma R, Lall N. Antibacterial, antioxidant activities and cytotoxicity of plants against Propionibacterium acnes. S Afr J Sci 2014;110:1-8.

71. Cock I, Van Vuuren S. South African food and medicinal plant extracts as potential antimicrobial food agents. J Food Sci Technol 2015;52:6879-99.

72. Akhalwaya S, Van Vuuren S, Patel M. An in vitro investigation of indigenous South African medicinal plants used to treat oral infections. J Ethnopharmacol 2018;210:359-71.

73. Dzoyem JP, Aro AO, McGaw LJ, Elof JN. Antimycobacterial activity against different pathogens and selectivity index of fourteen medicinal plants used in Southern Africa to treat tuberculosis and respiratory ailments. S Afr J Bot 2016;102:70-4.

74. Muchuweti M, Nyamukonda L, Chagonda LS, Ndhlala AR, Mupure C, Benhura M. Total phenolic content and antioxidant activity in selected medicinal plants of Zimbabwe. Int J Food Sci Technol 2006;41:33-8.

75. Mzindle NB. Anti-Inflammatory, Anti-Oxidant and Wound-Healing Properties of Selected South African Medicinal Plants. MSc Dissertation. Durban: Durban University of Technology; 2017.

76. Frum Y, Viljoen AM. In vitro 5-lipoxygenase activity of three indigenous South African aromatic plants used in traditional healing and the stereospecific activity of limonene in the 5-lipoxygenase assay. J Essent Oil Res 2006;18:85-8.

77. Zheng YT, Chan WL, Chan P, Huang H, Tam SC. Enhancement of the anti-herpetic effect of trichosanthin by acyclovir and interferon. FEBS Lett 2001;496:139-42. 